\title{
THE EFFECTS OF JOB COGNITION AND PERSONALITY TYPE ON AUDITOR JUDGMENT
}

\author{
Wimpie Yustino Setiawan ${ }^{1}$, Tabita Indah Iswari ${ }^{2}$ \\ Universitas Atma Jaya Yogyakarta \\ e-mail: wimpie_yustino@mail.uajy.ac.id \\ e-mail: tabita.indah@mail.uajy.ac.id
}

\begin{abstract}
Despite the fact that much research on factors influencing auditor judgment has been carried out, job cognition and personality type have received little attention from behavioral researches. This study aims to investigate empirical evidence of the effect of job cognition and personality type on auditor judgment. Mail questionnaires were used to collect data from auditors working at public accounting firms in Jakarta and Surabaya.The multiple regression analysis conducted to test the research hypotheses shows that personality type significantly influences auditor judgment. However, the research does not find any empirical evidence that job cognition has a significant effect on auditor judgment.
\end{abstract}

Keywords: Job Cognition, Personality Type, Auditor Judgment http://dx.doi.org/10.20885/jsb.vol20.iss1.art2

\begin{abstract}
Abstrak
Meski telah banyak penelitian yang mempelajari faktor-faktor yang mempengaruhi penilaian auditor, namun variabel kognisi pekerjaan dan tipe personalitas masih kurang mendapat perhatian dalam riset-riset keperilakuan. Riset ini bertujuan untuk menguji bukti empirik mengenai pengaruh kognisi pekerjaan dan tipe personalitas pada penilaian auditor. Teknik kuesioner surel digunakan untuk mengumpulkan data dari para auditor yang bekerja di perusahaan akuntan publik di Jakarta dan Surabaya. Analisis regresi berganda digunakan untuk menguji hipotesis penelitian yang menunjukkan bahwa tipe personalitas signifikan mempengaruhi penilaian auditor. Namun, hasil analisis tidak mengkonfirmasi adanya bukti empirik bahwa kognisi pekerjaan signifikan mempengaruhi penilaian auditor.
\end{abstract}

Kata kunci: kognisi pekerjaan, tipe personalitas, penilaian auditor

\section{INTRODUCTION}

Since the Enron scandal in 2001, there has been a growing interest in issues relating to auditor judgment. Auditor judgment is defined as "any decision or evaluation made by an auditor, which influences or governs the process and outcome of an audit of financial statements" (Wedemeyer, 2010, p.320).

This judgment includes assessing the risks of material misstatements of financial statements, performing audit procedures to address those risks, evaluating audit evidence, and forming an opinion on the financial statements. Auditor judgment is of crucial importance in the audit of financial statements, because it directly determines audit quality (Wedemeyer, 2010). For this reason, much research has been undertaken to examine the factors that influence auditor judgment.

Nevertheless, much research undertaken so far on auditor judgment has overlooked the significance of job cognition, which is an essential component of job satisfaction. Job cognition has long been known to be related to major employee variables, such as employee commitment, turnover and performance (Tekell, 2008). Cognitions are often described as "the content of thoughts or beliefs about an atttude object or statement of fact in question, usually in comparison to a standard or expectation" (Tekell, 2008, p.5).

A discrepancy between expectation and reality may lead to dissatisfaction and,in turn, poor performance. For example, an auditor who 
expects a certain level of autonomy but finds himself being overly micro-managed by his manager may feel dissatisfied with his job, which in turn may negatively affect his audit judgment.

In addition to the significant role of cognitions, research has also suggested that personality does influence decision making by individuals (Robbins \& Judge, 2013). According to Friedman and Rosenman (1974), who introduced Type A and Type B personality theory, people with Type A personality tend to be very ambitious, competitive, achievementoriented, impatient, anxiousand rigidlyorganized.In contrast, Type B individuals are more relaxed, non-competitive,and experience lower levels of stress and anxiety.Based on this theory of personality, auditors with Type A personality are suspected to have a high commitment and tendency to avoid failure, and thus are more likely to strictly follow audit standards and guidelines in making their judgment.

Unfortunately, despite the important role of job cognition and personality variables in decision-making, job cognition and personality have received very little attention from behavioral researchers. For many years, research on factors influencing auditor judgment has mainly been focused on extrinsic rewards such as financial incentives (e.g. Arifuddin, 2014; Bonner \& Sprinkle, 2002; Lee, 2012; MohdSanusi \&Mohd-Iskandar, 2006), while research on personality and auditor judgment is still very little (e.g. Kristianti, 2012). Therefore, this present research aims to fill this existing gap in research literature on auditor judgment by finding evidence on whether job cognition and personality type influence auditor judgment. The results of this study will provide new insights and a better understanding of the factors that affect auditor decision making, and also help audit firms in improvingtraining programs to enhance auditor judgment.

\section{LITERATURE REVIEW AND HYPO- THEE S DEVELOPMENT}

\section{Auditor Judgment}

Wedemeyer (2010, p. 320) defines auditor judgment as:

"any decision or evaluation made by an auditor, which influences or governs the process and outcome of an audit of financial statements".
Auditor judgment is regarded as the most essential element of the preparation and auditing of financial statements, because it strongly and directly influences audit quality, which is

"the degree to which an audit provides a basis for belief that financial statements do not contain material misstatements after the completion of the audit" (Wedemeyer, 2010).

The quality of auditor judgment is important because not only can it affect the professional reputation of the auditor, but it can also impact other stakeholders, such as employees, investors, and various organizations (Mala \& Chand, 2015). Professional judgments that an auditor should make in the audit of financial statements include (Wedemeyer, 2010): 1) The assessment of the risks of material misstatements of financial statements, including the potential effects of fraud, bias and business risk. 2) The identification, performance and assessment of audit procedures to address those risks. 3) The evaluation of audit evidence to determine the quality and meaning of that evidence and to assess the need for additional evidence based on the process. 4) The formation of an opinion on the financial statements and the decision whether or not to express that opinion.

The judgments that are made by competent auditors could reasonably vary, although they may use the same facts (Martinov-Bennie \& Pflugrath, 2009; Wedemeyer, 2010). This suggests that auditor judgment may be influenced by many factors. For this reason, much research has been undertaken to understand the factors that influence auditor judgment. For example, a research done by Mohd-Sanusi and Mohd-Iskandar (2006)showsthatthere is a pos itive relationship between performance incentive variables (financial incentives and feedback) and audit judgment performance.Other research (e.g. Arifuddin, 2014; Bonner \& Sprinkle, 2002; Lee, 2012) also shows support for the relationship between financial incentives and auditor judgment. In another study, Haron, Hartadi, Ansari, dan Ismail (2009) find evidence that auditor judgment on going concern opinion is affected by the financial indicators, evidence, and disclosure. Meanwhile, Järvinen's (2012) study reveals that auditor experience (i.e. experience in years) affectsthe auditor decision-making process, particularly 
from the information acquisition and usage perspective. Nevertheless, the significance of job cognition has been overlooked by research so far conducted on factors affecting auditor judgment.

\section{Job Cognition and Auditor Judgment}

Cognitions are regarded as a significant element of job satisfaction (Tekell, 2008). They are often described as

"the content of thoughts or beliefs about an attitude object or statement of fact in question, usually in comparison to a standard or expectation" (Tekell, 2008, p.5).

One's job cognition reflects the degree to which job facets (e.g. salary, appreciation, job condition, and career advancement opportunities) are deemed satisfactory when the individuakvaluate $\mathrm{s}$ and compares them with his own objectives.A low level of job cognition, that is, when a discrepancy between expectation and reality occurs, may lead to low job satisfaction and, in turn, poor performance. For example, an auditor who expects a certain level of autonomy but finds himself being overly micro-managed by his manager may feel dissatisfied with his job. This in turn may result in a poor audit judgment and poor audit quality.

Sahuand Pathardikar (2014) categorize job cognitions into two variables, namely intrinsic job cognitions and extrinsic job cognitions. Intrinsic job cognitions are the inner desire to use competencies and abilities in the job, whereas extrinsic job cognitions are the extrinsic elements of the job at workplace, such as supervisors' influence, amount of work, opportunities to grow, recognition, and interpersonal relations (Sahu\&Pathardikar, 2014, p. 3). Sahu and Pathardikar (2014) also argue that the performance of employees may vary despite the fact that they are provided with similar benefits, and this may be caused by the difference in the level of job cognition of each individual employee. In the same way, auditors provided with, for example, the same financial incentives may make different judgments, due to different job cognition levels that affect each individual audior.

Job cognition plays an important role in the workplace, because

"cognition of one's job or job experience influences positive emotions and these emotions or perceptions affect performance" (Sahu \& Pathardikar, 2014, p. 3).

Job cognition has long been known to be related to major employee outcomes, such as employee behavior, commitment, turnover and performance (Tekell, 2008). The results of Moorman's (1993) research, for example, find evidence that job cognitionis strongly related to organizational citizenship behavior (OCB). Lee and Allen (2002) also show support for the strong correlation between job cognition and OCB. Meanwhile, a research conducted by Sahu and Pathardikar (2014) suggests that extrinsic job cognitions influence organizational attachment.

Despite the fact that much research onjob cognition has been undertaken for many years, the relationship between job cognition and audior judgment has been overlooked by behavioral researchers. Therefore, the present research seeks to find evidence of the influence of job cognition on auditor judgment. Since previous research has shown that job cognition has a strong correlation with major employee outcomes (e.g. Lee \& Allen, 2002; Moorman, 1993; Sahu \& Pathardikar, 2014), it is expected that auditors' cognition of their job will affect their audit judgments. Thus, the first hypothesis of this research is formulated as follows:

Hypothesis 1 (H1): Job cognition will significantly affect auditor judgment.

\section{Personality Type and Auditor Judgment}

Research on personality and decision making suggests that personality does influence decision making by individuals (Robbins \& Judge, 2013). Gordon Allport (Robbins \& Judge, 2013 , p. 167), in the most frequently cited definition of personality, states that personality is "the dynamic organization within the individual of those psychophysical systems that determine his unique adjustments to his environment."

In this definition, personality is seen as the ways an individual reacts to and interacts with other people.

Friedman and Rosenman (1974) introduced Type A and Type B personality theory, in which they categorize personality into two types, namely Type A and Type B personalities. People with Type A personality are described to be very ambitious, competitive, achievement-oriented, impatient, anxious and 
rigidly-organized. These individuals generally have a strong desire to overcome challenges and achieve their goals. In contrast, Type B individuals are more relaxed, non-competitive, and experience lower levels of stress and anxiety. Based on this theory of personality, auditors with Type A personality are suspected to have a high commitment and tendency to avoid failure, and thus are more likely to strictly follow professional standards and guidelines in making their judgment.

A number of behavioral studies have investigated whether auditor personality and individual characteristics affect auditor behavior. For instance, a study by Iswari and $\mathrm{Ku}-$ suma (2013) shows that personality type has a moderating effect on the influence of organizational professional conflict on auditor professional judgment. Utami and Nahartyo (2013) find evidence that Type A personality intensifies the influence of role conflict and role overload on auditor burnout. This means that, due to their tendency to experience anxiety and impatience, auditors with Type A personality are more susceptible to work-related stress. Meanwhile, Kristianti (2012) finds no evidence that suppors the influence of personality on auditor judgment. Overall, the results of research done so far on the relationship between auditor personality and auditor behavior are still inconclusive, and more studies are needed.

Despite the inconclusive results and the lack of research on the auditor personality auditor behavior relation, some research has confirmed that there is a relationship between Type A personality and ethical orientation. For instance, Rayburn and Rayburn (1996) find evidence that Type A personalities are more ethically-oriented than Type B personalities. This conclusion is also supported by the research findings of Chadegani, Mohamed and Iskandar (2015) that show a significant rela- tionship between auditor personality and auditor intention to report errors. The study demonstrates that arguably due to their high co mmitment to the profession, auditors with Type A personality have more intention to report errors than their Type B counterparts.Based on the results of these studies, together with Type A and Type B personality theory proposed by Friedman and Rosenman (1974), it can be argued that auditors with Type A personality, who are more achievement-oriented, ethicaloriented, and tend to avoid failure, are more likely to make higher quality professional judgments than Type B auditors. Therefore, auditors with a greater tendency toward Type A personality is expected toproduce higher quality auditor judgment, as stated in the second research hypothesis below:

Hypothesis 2 (H2): Tendency toward Type A personality will significantly affectauditor judgment.

\section{RESEARCH METHODS}

\section{Sample and Data}

The population of this research is all auditors working at public accounting firms in Indonesia, while the sample comprises auditors working at public accounting firms in Jakarta and Surabaya. Auditors in Jakarta and Surabaya were selected as samples, because these cities are Indonesia's two largest cities by population according to the survey conducted by the Ministry of Health Republic of Indonesia (Kementerian Kesehatan Republik Indonesia,2014), and many head offices of major audit firms are located in these two cities. By using convenience sampling method, one hundred mail questionnaires were sent out to respondents, from which 45 responses were received, representing a response rate of $45 \%$.

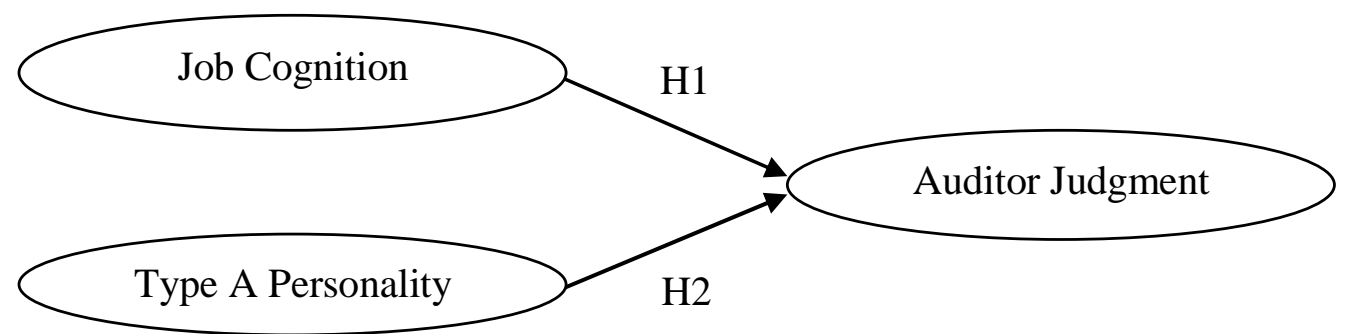

Figure 1 Study Framework 
Table 1: Profile of Respondents

\begin{tabular}{|c|c|c|c|}
\hline \multicolumn{2}{|c|}{ Demographic Profile } & \multirow{2}{*}{$\begin{array}{r}\begin{array}{l}\text { Number of } \\
\text { respondents }\end{array} \\
26\end{array}$} & \multirow{2}{*}{$\begin{array}{r}\text { Percentage } \\
58 \%\end{array}$} \\
\hline \multirow{3}{*}{ Sex } & Male & & \\
\hline & Female & 19 & $42 \%$ \\
\hline & Total & 45 & $100 \%$ \\
\hline \multirow{7}{*}{ Age (years) } & $<25$ & 16 & $36 \%$ \\
\hline & $25-30$ & 17 & $38 \%$ \\
\hline & $>30-35$ & 6 & $13 \%$ \\
\hline & $>35-40$ & 2 & $4 \%$ \\
\hline & $>41-45$ & 3 & $7 \%$ \\
\hline & $>45$ & 1 & $2 \%$ \\
\hline & Total & 45 & $100 \%$ \\
\hline \multirow{5}{*}{ Education } & Diploma & 2 & $4 \%$ \\
\hline & Undergraduate & 35 & $78 \%$ \\
\hline & Master & 6 & $13 \%$ \\
\hline & Doctorate & 2 & $4 \%$ \\
\hline & Total & 45 & $100 \%$ \\
\hline \multirow{6}{*}{ Position } & Junior Auditor & 23 & $51 \%$ \\
\hline & Senior Auditor & 17 & $38 \%$ \\
\hline & Assistant Manager & 2 & $4 \%$ \\
\hline & Senior Manager & 2 & $4 \%$ \\
\hline & Director & 1 & $2 \%$ \\
\hline & Total & 45 & $100 \%$ \\
\hline
\end{tabular}

From a total of 45 respondents, 26 (58\%)were male and 19 (42\%)were female. Most of them were aged between 25 and 30 (38\%) and below 25 (36\%). Thirty-five respondents $(78 \%)$ had attained undergraduate degree, and 6respondents (13\%) had received master's degree. Fifty-one percent of the respondents were junior auditors, $38 \%$ were senior auditors, while the others were assistant managers (4\%), senior managers $(4 \%)$, and a director $(2 \%)$. Table 1 summarizes the demographic profile of the respondents.

\section{Research Instrument}

This research uses structured questionnaires as its instrument to collect data from auditors. The questionnaire is divided into four sections, namely section $A$, section $B$, section $C$, and section D. Section A collects individuals' demographic information, like sex, age, education and the position they hold at the public accounting firm. Section B assessesthe personality type of auditors by using 17 items on seven- point Likert-type scales, which are a modified version of the Jenkins Activity Survey and were used by Iswari and Kusuma (2013) and Utami and Nahartyo (2013). In this section, participantswere required to indicate their levels of agreement or disagreement for 17 statements on a 7-point scale, where $1=$ strongly disagree, 2 = disagree, 3 = somewhat disagree, $4=$ neither agree nor disagree, $5=$ somewhat agree, $6=$ agree, and $7=$ strongly agree. Item responses were then summed to create a total score for personality type, with 119 being the highest possible score. A high score indicates a greater tendency toward Type A personality.

Section C employsan instrument developed by Dyne, Graham, and Dienesch in the Mas'ud (2004) to measure the level of job cognition of auditors. It contains 20 items on the same seven-point Likert-type scalesused in section B. The maximum possible score for this variable is $20 \times 7=140$ points, with high scores indicating greater levels of job cognition.Section D measures the quality of auditor 
judgment by utilizing the instrument used by Jamilah, Fanani, and Chandrarin (2007). This instrument consists of five case scenarios, with one question for each case scenario, in which the participants were required to indicate their responses on a seven-point Likert-type scales, where $1=$ very unlikely, $2=$ unlikely, $3=$ somewhat unlikely, $4=$ undecided, $5=$ somewhat likely, $6=$ likely, and $7=$ very likely. A total score for auditor judgment was acquired bysumming the item responses. The highest possible score for this variable is $5 \times 7=35$ points.A high scoresuggests a high quality auditor judgment, while a low score indicates a low quality auditor judgment.

\section{RESULTS AND DISCUSSION}

\section{Validity Test}

The validity of research instruments is tested by using the Pearson product-moment correlation coefficient, where they will be considered valid if the Pearson correlation value is greater than 0.3 (Arifuddin, 2014). The test results show that the Pearson correlation values of the instruments for all three variables are greater than 0.3 . Therefore, the instruments of this research are declared valid. These results are presented in Table 2.

\section{Reliability Test}

Research instruments are generally considered reliable if Cronbach's Alpha is greater than 0.6 (Arifuddin, 2014; Chadegani, Mohamed \&Iskandar, 2015; Iswari \& Kusuma, 2013; Utami \& Nahartyo, 2013). The reliability test of this research shows that the values of Cronbach's Alpha of the research instruments for all three variables are greater than 0.6, and thus are reliable. These reliability statistics are presented in Table 3.

Table 2: Validity Test Results

\begin{tabular}{|c|c|c|c|c|c|c|c|c|}
\hline \multicolumn{3}{|c|}{ Personality Type } & \multicolumn{3}{|c|}{ Job Cognition } & \multicolumn{3}{|c|}{ Auditor Judgment } \\
\hline Item & $\begin{array}{c}\text { Pearson } \\
\text { Correlation }\end{array}$ & Result & Item & $\begin{array}{l}\text { Pearson } \\
\text { Correlation }\end{array}$ & Result & Item & $\begin{array}{l}\text { Pearson } \\
\text { Correlation }\end{array}$ & Result \\
\hline PT1 & 0.304482 & Valid & $\mathrm{JC} 1$ & 0.357146 & Valid & $\mathrm{AJ} 1$ & 0.685310 & Valid \\
\hline PT2 & 0.390033 & Valid & $\mathrm{JC} 2$ & 0.741372 & Valid & $\mathrm{AJ} 2$ & 0.470337 & Valid \\
\hline PT3 & 0.544500 & Valid & $\mathrm{JC} 3$ & 0.644797 & Valid & $\mathrm{AJ} 3$ & 0.791715 & Valid \\
\hline PT4 & 0.531980 & Valid & $\mathrm{JC} 4$ & 0.705882 & Valid & AJ4 & 0.508860 & Valid \\
\hline PT5 & 0.304762 & Valid & JC5 & 0.705301 & Valid & AJ5 & 0.698211 & Valid \\
\hline PT6 & 0.542523 & Valid & JC6 & 0.706013 & Valid & & & \\
\hline PT7 & 0.627676 & Valid & $\mathrm{JC7}$ & 0.392411 & Valid & & & \\
\hline PT8 & 0.503563 & Valid & $\mathrm{JC} 8$ & 0.750218 & Valid & & & \\
\hline PT9 & 0.641995 & Valid & JC9 & 0.852490 & Valid & & & \\
\hline PT10 & 0.595043 & Valid & $\mathrm{JC} 10$ & 0.794692 & Valid & & & \\
\hline PT11 & 0.344078 & Valid & $\mathrm{JC} 11$ & 0.819175 & Valid & & & \\
\hline PT12 & 0.538273 & Valid & $\mathrm{JC} 12$ & 0.681676 & Valid & & & \\
\hline PT13 & 0.636232 & Valid & $\mathrm{JC} 13$ & 0.590437 & Valid & & & \\
\hline PT14 & 0.531409 & Valid & $\mathrm{JC} 14$ & 0.722565 & Valid & & & \\
\hline PT15 & 0.674452 & Valid & $\mathrm{JC} 15$ & 0.741618 & Valid & & & \\
\hline PT16 & 0.585731 & Valid & JC16 & 0.764209 & Valid & & & \\
\hline \multirow[t]{4}{*}{ PT17 } & 0.573292 & Valid & $\mathrm{JC} 17$ & 0.702040 & Valid & & & \\
\hline & & & $\mathrm{JC} 18$ & 0.769571 & Valid & & & \\
\hline & & & JC19 & 0.738880 & Valid & & & \\
\hline & & & $\mathrm{JC} 20$ & 0.747186 & Valid & & & \\
\hline
\end{tabular}


Table 3: Reliability Test Results

\begin{tabular}{|c|c|c|c|}
\hline \multirow[b]{2}{*}{ Variables } & & \multicolumn{2}{|c|}{ Reliability Statistics } \\
\hline & & $\begin{array}{l}\text { Cronbach's } \\
\text { Alpha }\end{array}$ & Result \\
\hline Personality Type & & 0.830996789 & Reliable \\
\hline Job Cognition & & 0.941241664 & Reliable \\
\hline Auditor Judgment & & 0.630142109 & Reliable \\
\hline \multicolumn{4}{|c|}{$\begin{array}{l}\text { Table 4: Descriptive Statistics } \\
\text { Descriptive Statistics }\end{array}$} \\
\hline Variables & Mean & $\begin{array}{c}\text { Standard Devia- } \\
\text { tion }\end{array}$ & $\mathbf{N}$ \\
\hline Personality_Type & 55.0889 & 14.15470 & 45 \\
\hline Job_Cognition & 99.5333 & 21.47260 & 45 \\
\hline Auditor_Judgment & 19.5111 & 6.25817 & 45 \\
\hline
\end{tabular}

\section{Descriptive Statistics}

Descriptive statistics show that the mean score of personality type is 55.09 out of 119 , with a standard deviation of 14.15 . The average score of job cognition is 99.53 out of 140 , with a standard deviation of 21.47. Meanwhile, the mean score of auditor judgment for all 45 auditors was 19.51 out of 35 , with a standard deviation of 6.26.These results are summarized in Table 4.

\section{Hypotheses Test Results and Interpretation}

From the multiple regression analysis undertaken to test the research hypotheses, three results are obtained. First, the model summary presented in Table 5 provides a measure of the quality of the prediction of the dependent variable (i.e. auditor judgment). The coefficient of determination $\left(\mathrm{R}^{2}\right)$ shows that the independent variables of this research (i.e. job cognition and personality type) explain 0.163 (or 16.3\%)of the variability of the dependent variable (i.e. auditor judgment). Mala and Chand (2015), for ex- ample, categorize factors that influence accounting and auditing judgment and decision making into three broadcategories, namely personal variables (e.g. knowledge, expertise, information-processing capabilities, and prior beliefs), task-related variables (e.g. task complexity and risk) and environmental variables (e.g. time pressure, internal control, corporate governance, and accountability).Hence, job cognition and personality type, which can be classified as personal variables, are only two among vast numbers of variables that influence auditors' decision making.

Second, the analysis shows that, despite the low R-squared value, the ANOVA table (see Table 6) indicates that the regression model predicts the dependent variable (i.e. auditor judgment) significantly well. This can be seen from the p-value of 0.024 , which is less than 0.05 , indicating that job cognition and personality type simultantly predict auditor judgment.

Table 5: Model Summary Model Summary

\begin{tabular}{lcccc}
\hline Model & R & R Square & $\begin{array}{c}\text { Adjusted R } \\
\text { Square }\end{array}$ & $\begin{array}{c}\text { Std. Error of } \\
\text { the Estimate }\end{array}$ \\
\hline 1 & $.403^{\mathrm{a}}$ & .163 & .123 & 5.86100 \\
\hline a. Predictors: (Constant), Personality_Type,Job_Cognition
\end{tabular}


Table 6. ANOVA Table

ANOVA $^{b}$

\begin{tabular}{llrrrrr}
\hline & Model & \multicolumn{1}{c}{$\begin{array}{c}\text { Sum of } \\
\text { Squares }\end{array}$} & df & Mean Square & F & Sig. \\
\hline 1 & Regression & 280.491 & 2 & 140.246 & 4.083 & $.024^{\mathrm{a}}$ \\
& Residual & 1442.753 & 42 & 34.351 & & \\
Total & 1723.244 & 44 & & & \\
\hline
\end{tabular}

a. Predictors: (Constant), Personality_Type, Job_Cognition

b. Dependent Variable: Auditor_Judgment

Table 7. Coefficients Table

\begin{tabular}{|c|c|c|c|c|c|c|c|c|}
\hline & \multicolumn{8}{|c|}{ Coefficients $^{\mathrm{a}}$} \\
\hline & \multirow{2}{*}{ Model } & \multicolumn{2}{|c|}{$\begin{array}{l}\text { Unstandardized } \\
\text { Coefficients }\end{array}$} & \multirow{2}{*}{$\begin{array}{c}\begin{array}{c}\text { Standardized } \\
\text { Coefficients }\end{array} \\
\text { Beta }\end{array}$} & \multirow{2}{*}{$\mathbf{t}$} & \multirow{2}{*}{ Sig. } & \multicolumn{2}{|c|}{$\begin{array}{l}\text { 95\% Confidence } \\
\text { Interval for B }\end{array}$} \\
\hline & & B & $\begin{array}{l}\text { Std. } \\
\text { Error }\end{array}$ & & & & $\begin{array}{l}\text { Lower } \\
\text { Bound }\end{array}$ & $\begin{array}{l}\text { Upper } \\
\text { Bound }\end{array}$ \\
\hline \multirow[t]{3}{*}{1} & (Constant) & 8.778 & 5.586 & & 1.571 & .124 & -2.496 & 20.051 \\
\hline & Job_Cognition & .009 & .041 & .031 & .217 & .829 & -.074 & .092 \\
\hline & Personality_Type & .179 & .063 & .404 & 2.857 & .007 & .052 & .305 \\
\hline
\end{tabular}

a. Dependent Variable: Auditor_Judgment

Finally, the coefficients table (Table 7) indicates the level of statistical significance of each of the independent variables (i.e. job cognition and personality type). The hypotheses of this research will be accepted if the $p$-value is less than 0.05 , and rejected if the $p$-value is greater than 0.05 . The table shows that the $p$ value for job cognition is 0.829 , which is much greater than 0.05 . This means that job cognition does not significantly influence auditor judgment. Therefore, the first hypothesis of this research - job cognition will significantly affect auditor judgment - is rejected. This result may be explained by the fact that in performing their duties and making decisions, regardless of the level of their job cognition, auditors are bound by strict ethical and professional standards (Patel, Harrison, \& McKinnon, 2002). In Indonesia, these ethical and professional standards are contained in the Professional Standards of Public Accountants, which are set and enforced by the Indonesian Institute of Chartered Accountants (Ikatan Akuntan Indonesia, or IAI). Any breach of these standards will have dire consequences for auditors, such as damages to their reputation and termination of employment (Patel, et al. 2002).

Meanwhile, the $p$-value for personality type is 0.007 , which is less than 0.05 , indicat- ing that personality type significantly affectsauditor judgment. The second hypothesis of this research, that a tendency toward Type A personality will significantly affect auditor judgment, is thus accepted. This result suggests that, from the perspective of Type A and Type B personality theory proposed by Friedman and Rosenman (1974), auditors with a greater tendency toward Type A personality are generally achievement-oriented and hate to fail, and, therefore, are more likely to produce higher quality audit judgments. This supports the findings of previous research on personality and decision making that has found a significant relationship between Type A personality and ethical orientation (e.g. Chadegani, Mohamed \&Iskandar, 2015; Rayburn \& Rayburn, 1996).

\section{CONCLUSIONS, IMPLICATIONS, LIMI- TATIONS, AND RECOMMENDATIONS}

\section{Conclusions and Implications}

This research investigates the influence of job cognition and personality type on auditor judgment. The multiple regression analysis conducted to test the research hypotheses shows two results. First, this study finds empirical evidence of the effect of personality on auditor judgment. Auditors with a greater ten- 
dency toward Type A personality are found to have higher quality audit judgments. However, the research does not find any evidence of the effect of job cognition on auditor judgment. The analysis reveals that job cognition does not significantly affect auditor judgment.

The results of this study have several important implications. First, since job cognition, which is a subjective variable, does not significantly affect auditor judgment, then auditor judgment may be influenced and improved by more objective factors such as ethical and professional standards. These ethical and professional standards play an important role in increasing the quality of auditor judgment, because regardless of the level of their job cognition, auditors are strictly bound by these standards and will face serious consequences if they breach them. Second, this study brings valuable insights into the behavioral field, because for many years there has been little research conducted on the relationship between personality and decision making. The result of this study suggests that personality type does influence auditors' decision making. Therefore, as the practical implication of this finding, accounting firms should pay more attention to individual differences, especially personality type, and plan training programs that will encourage auditors with a greater tendency toward Type A personality to maintain their high quality audit judgments and will motivate auditors with a greater tendency toward Type B personality to improve their audit judgments.

\section{Limitations and Recommendations}

This research has several limitations. First, it involves only auditors working at public accounting firms in Jakarta and Surabaya as samples. Second, it does not distinguish auditor judgment based onthe auditors' position at the accounting firm, their education, and tenure. Third, this research only employs mail questionnaires which are vulnerable to manipulation by respondents. Therefore, it is hoped that more studies on job cognition, personality type, and auditor judgment will be carried out in the future with more samples from other large cities in Indonesia, such as Bandung, Medan, Makassar, Palembang, Semarang, and other cities. It is also suggested that future research will distinguish auditor judgment based on their posi- tion, education and tenure at the accounting firm. Finally, other methods of collecting data are expected to be utilized in future research, for example, interviews or other methods which are less susceptible to manipulation.

\section{REFERENCE LISTS}

Arifuddin. 2014. The effect of performance incentive on audit judgment by using the effort as the intervening variable and the task complexity as the moderating variable. International Journal of Applied Business and Economics Research. 12(4). 1305-1314.

Bonner, SE and Sprinkle, GB. 2002. The effects of monetary incentives on effort and task performance: theories, evidence, and a framework for research. Accounting, Organizations and Society. 27 (4/5). 303-345.

Chadegani, AA, Mohamed, ZM, and Iskandar, TM. 2015.The Influence of Individual Characteristics on Auditors' Intention to Report Errors. Journal of Economics, Business and Management. 3(7). 710-714.

Friedman, M and Rosenman, R.1974. Type A Behavior and Your Heart. New York. Knopf.

Haron, H, Hartadi, B, Ansari, M and Ismail, I. 2009. Factors influencing auditors' going concern opinion. Asian Academy of Management Journal. 14 (1). 1-19.

Iswari, TI and Kusuma, IW. 2013. The Effect of Organizational-Professional Conflict towards Professional Judgment by Public Accountant Using Personality Type, Gender, and Locus of Control as Moderating Variables. Review of Integrative Business \& Economics Research. 2 (2). 434-448.

Jamilah, S, Fanani, Z and Chandrarin, G. 2007. Pengaruh gender, tekanan ketaatan, dan kompleksitas tugas terhadap audit judgment. In National Accounting Symposium X, Hasanuddin University, Makassar, 26-28 July 2007.<https://smartaccounting.files.wo 
rdpress.com/2011/03/auep06.pdf>. Retrieved on 26 Juni 2015.

Järvinen, T. 2012. Factors influencing auditors' information usage: experience, risk, task structure and information reliability. PhD thesis, University of Vaasa, Vaasa.

Kementerian Kesehatan Republik Indonesia. 2014. Estimasi Penduduk Menurut Umur Tunggal dan Jenis Kelamin Menurut Kabupaten/Kota Tahun 2014. <http://www.depkes.go.id/resourc es/download/general/Penduduk\%20Ka b\%20Kota\%20Umur\%20Tunggal\%20 2014.pdf>. Accessed 26 Juni 2015.

Kristianti, I. 2012. Pengaruh tipe kepribadian dan penerimaan perilaku disfungsional terhadap audit judgment. Master's Thesis, Satya Wacana Christian University, Salatiga.

Lee, H. 2012. Incentive contracts and time pressure on audit judgment performance. Managerial Auditing Journal. 27 (3). $263-283$.

Lee, K and Allen, NJ. 2002. Organizational citizenship behavior and workplace deviance: the role of affect and cognitions. Journal of Applied Psychology. 87 (1). 131-142.

Mala, R and Chand, P. 2015. Judgment and Decision-Making Research in Auditing and Accounting: Future Research Implications of Person, Task, and Environment Perspective. Accounting Perspective. 14(1). 1-50.

Martinov-Bennie, N., and Pflugrath, G. 2009. The strength of an accounting firm's ethical environment and the quality of auditors' judgments. Journal of Business Ethics. 87(1). 237-253.

Mas'ud, F. 2004. Survai Diagnosis Organisasional: Konsep \& Aplikasi. $4^{\text {th }}$ edn.Semarang. Badan Penerbit Universitas Diponegoro.
Mohd-Sanusi, Z and Mohd-Iskandar T. 2006. Audit judgment performance: assessing the effect ofperformance incentives, effort and task complexity. Managerial Auditing Journal. 22 (1). 34 - 52.

Moorman, RH. 1993. The influence of cognitive and affective based job satisfaction measures on the relationship between satisfaction and organizational citizenship behavior. Human Relations. 46(6). 759-776.

Patel, C., Harrison, G. L., and McKinnon, J. L. 2002. Cultural influences on judgments of professional accountants in auditorclient conflict resolution. Journal of International Financial Management and Accounting. 13(1). 1-31.

Rayburn, J.M. and Rayburn, L.G. 1996. Relationship between Machiavellianism and Type A personality and ethicalorientation. Journal of Business Ethics. 15 (11). 1209-1219.

Robbins, SP and Judge, TA. 2013. Organizational Behavior. $15^{\text {th }}$ edn. Pearson Education Limited.

Sahu, S. and Pathardikar, AD. 2014. Job cognition and justice influencing organizational attachment: an assessment through SEM. SAGE Journals. 4 (1). 112.

Tekell, JK. 2008. Affective and cognitive components of job satisfaction: scale development and initial validation. Master's Thesis, University of North Texas, Denton.

Utami, I and Nahartyo, E. 2013. The effect of type a personality on auditor burnout: Evidence from Indonesia. Accounting \& Taxation. 5 (2). 89-102.

Wedemeyer, PD. 2010. A discussion of auditor judgment as the critical component in audit quality - A practitioner's perspective. International Journal of Disclosure and Governance. 7 (2). 320333. 